\title{
Taxation Criminal Acts Committed by Taxpayers and Related to Sustainable Development in Indonesia
}

\author{
B M Hasibuan ${ }^{1}$ and A Sofian ${ }^{2}$ \\ ${ }^{1,2}$ Faculty of Humanities, Universitas Bina Nusantara, Jakarta, Indonesia
}

batara.hasibuan@binus.ac.id

\begin{abstract}
Tax is one of sources of national income which contributes about $70 \%$ of the total state revenue. Taxes are also a source of income to support sustainable development. Unfortunately, about 2,000 legal entities/foreign investment companies have committed taxation criminal acts which are categorized as a tax evasion with various moduses for ten years. This causes Indonesia to lose state revenue about 100 trillion rupiahs. The research question is: What are the forms of taxation criminal acts which are regulated in Law Number 16 Year 2009 on General Provisions and Tax Procedures as a positive law in Indonesia? The formulation of the offense in the law is weak because it does not differentiate sanctions for an individual and a legal entity as a taxpayer. The authors suggest that the law should give different interpretations of crimes committed by an individual and crimes committed by a legal entity. In this context, an additional punishment must be imposed on a legal entity or a foreign investment company which commits a taxation criminal act that it will not cause financial loss to the state revenue.
\end{abstract}

Keywords: TAX, Criminal, Law

\section{INTRODUCTION}

Tax is one of sources of national income which contributes about $70 \%$ of the total state revenue [1]. Tax received by the state is used to finance various public needs. The more taxes that they collect, the more facilities and infrastructures they build. Therefore, tax is vital for state development, because it will support sustainable development efforts. Sustainable development is a national strategy in realizing a justice and prosperous society [2].

Therefore, it is vital for the government to take necessary efforts to increase tax revenue, including the implementation of tax amnesty as regulated in Law Number 11 Year 2016 on Tax Amnesty.

Panama Papers case also targets some high-ranking officials in Indonesia. It is believed that they intentionally hide their wealth abroad to avoid tax. This can be categorized as disobedience of tax obligations and may cause a big loss to the state revenue. It is estimated that the amount of their money and the value of their assets in tax havens exceed Indonesia's gross domestic product (GDP) which is about 11 thousand trillion rupiah [2]. 
The Panama Papers are documents published collectively by 100 media all over the world at the beginning of April 2016 which are initiated by the International Consortium Investigative Journalists (ICIJ) [3]. The Panama Papers are a financial document which gives information on how a law firm cooperates with a bank to reveal financial secrets. A total of 11.5 million documents containing data on politicians, drug mafia, millionaires, celebrities and world-class sports stars were leaked. They were involved in various black companies which are intentionally established in tax havens [3]. Based on the background above, this research is focused on the following research question: What are the forms of taxation criminal acts which are regulated in Law Number 16 Year 2009 on General Provisions and Tax Procedures?

\section{LITERATURE REVIEW}

The research method used in this research is the normative legal research method which is examining national laws on taxes and analysis of judicial decisions. This method uses primary legal materials in the form of Law Number 16 Year 2009 on General Provisions and Tax Procedures and Law Number 25 Year 2007 on Capital Investment. In addition, this study also uses secondary legal materials and tertiary legal materials. The analysis used is descriptive normative.

\section{RESULT AND DISCUSSION}

The main purpose of a research conducted by Friedrich Schneider is to explore size of the shadow economy, including tax evasion, of 31 European countries in 2014 and size of the shadow economy of 28 European Union countries over 2003-2014 (in percent of official GDP). An additional objective is to identify tax evasion, as the problem of all the EU countries, answering the questions how better combat the tax fraud [4].

Then, Mahrus Ali gives an explanation of elements or concepts of taxation criminal acts committed by a legal entity. The definition of crime committed by a legal entity is different from the definition of crime committed by an individual. One of the difference is that a corporation does not have any soul and thought but an individual has them. The difference has an implication on the construction of crime that will be used for a corporation so that it can be held responsible for crimes it has committed. Theory of operational actors and theory of identification are used as a juridical basis if a crime is committed by a corporation [5].

According to the theory of functional actors, the act is not necessarily done physically, but it can be done by its worker as long as it is still in the scope of the authoritative functions of the corporation. Meanwhile, according to the theory of identification, a corporation can directly commit a crime through people who are closely related to it and is perceived as the corporation itself. An act done by certain members of a certain corporation, as long as the act is related to the corporation, is perceived as the act of the corporation itself. Therefore, if the act causes loss, or in other words, if certain members of the corporation commit a crime, the crime is actually committed by the corporation so that it can be held responsible for the crime.

This paper discusses criminal taxation acts committed by a legal entity or a foreign investment company which can interfere with sustainable development. Therefore, the authors use the theory of tax evasion to answer the research question. Since tax evasion is a crime, the authors need to explain the concept of crimes first.

Michael J. Mcintyre states that tax evasion is an effort to illegally deduct tax that must be collected by not reporting incomes or through an intended money fraud. Meanwhile, Frans 
Vanistendael states that tax evasion is punishable. It includes falsifying documents, keeping double books, not reporting incomes as well as smuggling or hiding goods or wealth [4]

Tax evasion is a term used in economic, especially in tax. A taxpayer, in this context is an individual or a legal entity which does not correctly and honestly administer his or her obligation to the state or does not declare the amount of his or her tax to the state, may causes financial loss to the state. In addition, a number of legal entities try to do an act called unfair competition [5]. Other expert, Victor Thuronyi, says that tax evasion or tax fraud is an illegal act which is punishable under Law on Taxes [6].

Law on General Provisions and Tax Procedures recognizes 20 types of taxation criminal acts committLaw on General Provisions and Tax Procedures recognizes 20 types of taxation criminal acts committed by taxpayers with different criminal sanctions, starting from a fine to an imprisonment punishment. This crime can disrupt and even hamper sustainable development. The 20 types of taxation criminal acts committed by taxpayers are regulated in Article 38, Article 39, Article 39A, Article 41A, Article 41B and Article 41C of the law. Since taxation criminal acts committed by taxpayers have different elements and sanctions, they can be differentiated in a juridical context.

The differentiation of criminal taxation acts committed by taxpayers shows that there are different types of taxation criminal acts committed by taxpayers, starting from administrative crimes, criminal negligence, intended crimes and even planned crimes. Every criminal taxation act gives an alternative or cumulative principal punishment. In addition, there are various types and criteria of offenses in a criminal act such as formal offenses and material offenses, commission offenses and omission offenses, dolus offenses and culpable offenses, ordinary offenses and complaint offenses, etc. The different forms of taxation criminal acts above can be categorized based on their types and criteria and are further explained in the matrix below.

In the context of criminal taxation acts committed by taxpayers, the authors want to quote Moeljatno's view stating that every crime must consist of physical elements containing conduct and effect. Another aspect mentioned by Moeljatno is a circumstance element or in his language is called "events". In more detailed, there are five elements explained by Moeljatno: conduct and effect, events or circumstances accompanying an act, additional circumstances making crime more serious, objective illegal elements and subjective illegal elements [7]. Therefore, every act can be categorized as a crime if elements of the formulation of the crime are full filed.

In general, according to the Law on General Provisions and Tax Procedures, taxation criminal acts committed by taxpayers have at least five key elements: committed by anyone, fault, performing an act which breaches tax obligations, causing loss to state revenues and the availability of a (criminal) sanction. However, these elements do not absolutely adhere to every taxation criminal act. There is a taxation criminal act committed by a taxpayer but it does not cause any financial loss to state revenue. The authors further explain elements of taxation criminal acts below.

\subsection{Committed by Anyone}

Anyone as set forth in this provision is a taxpayer which is an individual or an entity based on Article 1 Paragraph (2) of Law on General Provisions and Tax Procedures. This element defines anyone who commits a taxation criminal act or a legal subject. In addition, the law gives a clear and detailed definition of an entity as a taxpayer as regulated in Article 1 Paragraph (3) of Law on General Provisions and Tax Procedures. 
In relation to collective investment contract and permanent establishment (PE) in investment, according to Law Number 25 Year 2007 on Capital Investment, legal entity which conducts capital investment can be divided into two: foreign capital investment legal entity (company) and domestic capital investment legal entity (company). In case the legal entity is a foreign capital investment, it shall be in the form of a limited liability company. This is one of government efforts to give legal certainty to foreign capital investment.

\subsection{Fault}

According to Simons, fault is a certain psychological condition of someone committing a criminal act and the existence of a relation between the condition and the act in such a way so that he or she can be reproached because of performing the act. Based on Simons' notion, Moeljatno says that fault has mental condition and act which rises reproach must be deliberation or negligence. Fault and negligence have the same basis, the existence of a prohibited and punishable act, the availability of capacity to be responsible and the absence of reason to forgive. However, they have different forms. In deliberation, offender's mental condition against the prohibited act because he or she wants an act and knows the result of the act [7]. In negligence, offender does not care about the prohibited act or is not careful in performing an act so that it causes a prohibited condition.

\subsection{Performing an Act which Breaches Tax Obligations}

Criminal act acknowledges commission of a delict (commissiedelicte) and ommission of a delict (omisiedelicten). Commission of a delict is a delict which is committed through a conduct. It means that the conduct is committed actively by violating law. Ommission of delict is a criminal act which occurs because of omission or neglect. Ommission of delict can be divided into two: pure ommission of delict and non pure ommission of delict. Pure ommission of delict is failure to do something which has been ordered. Meanwhile, non pure ommission of delict occurs when laws do not want a result (the result can be caused by a negligence).

An example of commission of delict can be found in Article 39 paragraph (1) point d of Law on General Provisions and Tax Procedures and an example of ommission of delict can be found in Article 39 paragraph (1) point a of Law on General Provisions and Tax Procedures.

\subsection{Causing Loss to State Revenue}

This element is vital in determining whether the act is a taxation criminal act and not an economic criminal crime. Taxation criminal act should not be categorized into a criminal act which cause loss to the state economy which is one of elements of corruption delict. Conversely, tax delict has an element "can cause loss to state revenue" which is clearly stated in the formulation of the delict. The formulation of delict in each article of criminal act committed by taxpayers must include the element "cause loss to state revenue" as a requirement for the fulfillment of tax delict.

However, Article 39A of Law on General Provisions and Tax Procedures which regulates two forms of taxation criminal acts states that anyone who deliberately (1) issues and/or utilizes the tax invoice, tax collection proof, tax withholding proof, and/ or tax payment proof that is not based on the real transaction; or (2) issues the tax invoice but it has been established as the taxable entrepreneur. The article does not contain 
the element of causing loss to the state revenues. It means that forms of taxation criminal acts contained in the article is a formal delict. It is performing certain acts which is prohibited in the formulation.

\subsection{Sanction}

In addition to the elements above, the Law on General Provisions and Tax Procedures also regulates a sanction for taxation criminal acts committed by taxpayers. According to R. Soesilo, a criminal sanction in the criminal law is a bad feeling imposed by judges on someone who violates a criminal provision. There are two criminal sanctions: principal punishment and additional punishment. Principal criminal punishment is divided into capital punishment, sentence of imprisonment, detention and fine. Meanwhile, additional criminal punishment can be divided into deprivation of certain rights, seizure of certain goods and announcement of judge's decision. Aspects of fine sanctions need special attention, because fines paid by perpetrators of tax crimes can be used to support development efforts.

Taxpayers who commit a taxation criminal act are subject to sanctions as regulated in Article 38, Article 39, Article 30A, Article 41, Article 41A, Article 41B and Article 41C of Law on General Provisions and Tax Procedures based on types of crimes he or she commits. It is hoped that the imposition of the sanction will encourage taxpayers to fulfill their tax obligations, prevent them from repeating their act and even prevent them from committing a taxation criminal act which will cause a big financial loss to the state.

The different forms of taxation criminal acts committed by taxpayers above can be interpreted as a tax evasion. This is in line with Michael J. Mcintyre's view stating that tax evasion is an effort to illegally deduct tax that must be collected by not reporting incomes or through an intended money fraud. This is also in line with Friedrich Schneider's view of tax evasion stating that a taxpayer, in this context is an individual or a legal entity which does not correctly and honestly administer his or her obligation to the state or does not declare his or her tax to the state, may causes financial loss to the state [4].

\section{CONCLUSION}

The forms of taxation criminal acts have a relation to legal subject which commits a taxation criminal act. Tax criminals can be divided into four categories: (1) taxpayers, (2) tax officials, (3) tax collectors, and (4) other parties. In addition, there are 25 forms of taxation criminal acts such as not submitting an annual tax report, falsifying notification letter, not register itself or report his or her business, etc. Taxation criminal acts committed by taxpayers that can be interpreted as tax evasion are regulated in Article 38, Article 39, Article 39A, Article 41A, Article 41B and Article 41C of the Law on General Provisions and Tax Procedures. Different from elements in the formulation of delict committed by Director General of Tax which is regulated in Article 36A of Law on General Provisions and Tax Procedure, the formulation of delict committed by tax official which is regulated in Article 41 of Law on General Provisions and Tax Procedures only has four elements.

Law on General Provisions and Tax Procedures should provide a detailed explanation of criteria or elements of individual legal subject and legal entity. The differences must be included in the future revision of Law on General Provisions and Tax Procedures so that it can help prosecutors determine legal subject/tax criminals and form of the taxation criminal act committed by the legal subject. Furthermore, this revision also ensures that tax crimes will 
guarantee sustainable development because the perpetrators of these tax crimes will be subject to fines so that these penalties will be used for development.

\section{REFERENCES}

[1] M. Iqbal, "Pajak Sebagai Ujung Tombak Pembangunan," Direktorat Jenderal Pajak Kementerian Keuangan, $2016 . \quad$ [Online]. Available: http://www.pajak.go.id/content/article/pajak-sebagai-ujung-tombak-pembangunan.

[2] M. Silalahi, I. Klara, and A. Anjar, "Jejak Korupsi Global dari Panama," Pusaka, 2016. [Online]. Available: https://pusaka.or.id/2016/04/jejak-korupsi-global-dari-panamahingga-tax-amnesty-indonesia/.

[3] S. Benk, T. Budak, S. Püren, and M. Erdem, "Perception of tax evasion as a crime in Turkey,” J. Money Laund. Control, vol. 18, no. 1, pp. 99-111, Jan. 2015.

[4] F. Schneider, K. Raczkowski, and B. Mróz, "Shadow economy and tax evasion in the EU," J. Money Laund. Control, vol. 18, no. 1, pp. 34-51, Jan. 2015.

[5] M. Ali, Kejahatan Korporasi Kajian Relevansi Sanksi Tindakan Bagi Penanggulangan Kejahatan Korporasi. Yogyakarta: Arti Bumintaran, 2008.

[6] V. Thuronyi, Tax Law Design and Drafting I. Washington DC: IMF, 1998.

[7] Moeljatno, Asas-asas Hukum Pidana. Jakarta: Bina Aksara, 1987. 